conducted by the author, parallels continue to be drawn between these individual experiences and expressions and their place within a wider network of contemporary (popular) cultural relations and productions.

Overall, Provencher's study is thought-provoking, clear, and insightful, entwining the global, the national, and the local in such a way as to maintain accessibility for readers with differing levels of knowledge of the specifics of the contemporary French context. Particularly useful are the brief sections that outline developments in recent scholarship in such areas as sexual citizenship and sociolinguistic analyses of coming out narratives. It is perhaps regrettable that, from the outset, globalisation and its impacts in the French context are equated primarily with the influence of the US. Without wishing to deny the crucial role played by tensions with the US in the development of French gay popular cultures, it would have been interesting to have read more about a truly globalised and globalising network of exchanges. Indeed, the author himself points towards further work to be done in this area in his conclusion that highlights the importance of a transnational dialogue between metropolitan France and the countries of North Africa, in particular. This criticism put to one side, however, Provencher's study offers an important contribution to contemporary considerations of a French republic that is global, transnational, and, crucially, 'always and already queer' (p. 146).

Cristina Johnston

\title{
references
}

Bell, D. and Binnie, J. (2000) The Sexual Citizen: Queer Politics and Beyond, Malden: Blackwell. Bersani, L. (1995) Homos, Cambridge: Harvard University Press.

doi: $10.1057 /$ fr. 2009.52

\section{queer transitions in contemporary Spanish culture: from Franco to La Movida}

Gema Pérez-Sánchez; State University of New York Press, Albany, New York, 2007, 257pp., ISBN 978-0-7914-7173-9, \$60.00 (hardback)

Queer Transitions in Contemporary Spanish Culture aims to show queer contributions in the negotiation of gender identities and sexual practices from the last years of the Franco dictatorship to the consolidation of democracy. Its specific contribution to the literature that analyses this period's cultural production is to combine an attention to lesbian novelists and artists with gay 
male authors, avoiding the usual masculine bias. Moreover, the author connects canonical literary texts with the analysis of 'low culture'. Her approach is influenced by Marxist-inflected cultural studies, psychoanalysis, queer theory and feminism.

The first chapter deals with the social and political situation in Spain at the end of Francoism, paying special attention to the hegemonic conception of gender. Pérez-Sánchez points out that the prosecution of homosexuality was necessary in order to draw boundaries limiting relationships between males. In fact, the repression of male homosexuality was the other side of the coin of the fascist worship of the youthful and vigorous male body and male camaraderie. According to the author, the repression of homosexuality plays a second role: since Spain was in the hands of foreign capital and was politically marginalized, the Francoist regime felt that the country was 'segregated to a passive role, [which meant] that the nation was being placed in the same position as women' ( $p .13$ ). This perception might have strengthened the dictatorship's obsession with normativizing gender and sexuality. It might have been interesting to include a more profound account of sexism in that period, since it appears as if this was exclusive to Francoist ideology, whereas this ideology was also present in different forms within the political opposition and in other countries (even those with democratic regimes).

In the second chapter, through an analysis of Ana Maria Moix's book, Julia, the author produces an interesting account of the dangers of the silence to which women, and specially lesbians, were condemned. Moix herself had to resort to silence in order to avoid censorship, to the extent that only a sensitive reader can realize the lesbianism of the main character and the feminist political message of the book. Hence, silence has an ambivalent role: while it provides a protection, a shelter, it can become a prison cell. Actually, at the end of the novel, Julia is defeated in her silence and condemned to live in a world where she can not find her own place. This dramatic conclusion, according to Pérez-Sánchez, is a clear denunciation of 'the oppressiveness of a heterosexist society that does not permit women to have voices of their own and that can not conceive of women desiring other women' (p. 59).

Beyond a doubt, the third chapter is the most complex and well articulated. Pérez-Sánchez is in dialogue with four novels written by male authors, each of whom question the constraints of masculinity and sexuality from different points of view and with opposing political effects. La familia de Pascual Duarte, by Cela, is considered the reference point for the other authors. Pascual is a man oppressed by his castrating mother, who is understood to be indirectly responsible for her son's numerous crimes: 'one might say that Pascual kills because he feels guilty for not measuring up to his and his culture's ideal vision of masculinity and that his guilt is triggered by what he interprets as the judgmental, castrating gaze of females' (p. 71). Hence, Pérez-Sánchez states 
that, while the novel aims to criticize fascist machismo, it eventually displays a misogynist representation of women, who are presented as deserving male violence.

The questioning of machismo within a misogynistic discourse is what Cela, Martín-Santos and Goytisolo's novels have in common. Martín-Santos' involvement in the fight against Francoism or Goytisolo's vindication of homosexuality as an alternative way of living do not guarantee that either of them display an anti-sexist discourse. Moreover, as Pérez-Sánchez shows, they reproduce Cela's conflation of women with the oppressive Francoist regime. This imaginary is contested by Mendicutti's Una mala noche la tiene cualquiera, in which the new democratic Spain is allegorized as a transvestite. This novel challenges both the dichotomous gender identities and the conception of the nation: Mendicutti 'highlights that all identities are always in transition' (p. 112).

In the fourth chapter, Peri Rossi's La nave de los locos is the context for a questioning of male writers' obsessions with Spanish nationhood, since the Uruguayan author proposes to understand foreignness and alienation as the conditions of contemporary times. Furthermore, Peri Rossi's considerations of gender connect with Judith Butler's performative conception of gender and its necessary intelligibility within a heteronormative frame.

The fifth and last chapter, which is less well structured than others, raises several interesting ideas about the representation of gender and sexuality in comic books published during the early years of democracy. On the one hand, the author analyses conceptions of gender and sexuality in three women's comic creations that appeared in Madriz, a magazine that wished to represent voices of marginalized groups, particularly women and sexual minorities, in a traditionally androcentric art field. On the other hand, she analyses another comic book, $\varepsilon l$ Vibora, which intended to be a subversive queer project. According to the author, behind the apparently radical image, this comic book (and specially Nazario's stories) reproduced the values of hypervirility and misogyny, which could be why, surprisingly, it appealed to a mainstream, conservative, heterosexual male readership.

Pérez-Sánchez certainly produces an interesting account of several queer contributions to cultural and social life during a crucial historical period in Spain. One of the most suggestive messages it delivers, from my point of view, is that leftists such as Martin Santos or gay authors like Goytysolo and Nazario reproduced misogynistic representations in their works. Thus, the book provides further evidence of the difficulty in finding allies in the fight against sexism, even within social groups politically engaged in social transformation projects.

doi: $10.1057 / f r .2009 .53$

Gerard Coll-Planas 